\title{
Oncogenes as Therapeutic Targets in Cancer: A Review
}

\author{
Rani Mol. $\mathrm{P}^{1}$, Anita Balan ${ }^{2}$ \\ ${ }^{\text {I}}$ (Department of Oral Medicine and Radiology, PMS College of Dental Science and Research, India) \\ ${ }^{2}$ (Department of Oral Medicine and Radiology, Government Dental College , Kozhikode, India)
}

\begin{abstract}
Carcinogenesis is a multi-step process which result in uncontrolled cell growth. Mutations in DNA that lead to cancer disrupt these orderly processes by disrupting the programming regulating the processes.. This results in uncontrolled cell division leading to carcinogenesis. Oncogenes are genes whose protein products stimulate or enhance the division and viability of cells. Oncogenes arise by activating mutation of their precursors, the proto-oncogenes. Proto-oncogenes are often directly involved in growth regulation of normal cells. Advances in molecular studies had led to the identification of many oncogenes in cancer formation. This will help in early detection of many cancers. The action of drugs on oncogenes will help in specific treatment of different types of cancers. An overview of the functions, properties and clinical importance of oncogenes is discussed in this review.
\end{abstract}

Keywords: cancer, cell cycle, oncogenes, cancer therapy

\section{Introduction}

Cancer is the result of uncontrolled cell growth. In cancer, the cells stops paying attention to the normal signals that tell cells to grow, stop growing or even to die. Cancer cells still share many of the same needs and properties of normal cells but they become independent of the controls that make our body function smoothly. The process by which a normal cell changes into one that behaves so abnormally can take a long time and is often triggered by outside influences. The changes are often the result of changes to the DNA (mutations) in the cells. The development of cancer takes place in a multi-step process. As the cells become more abnormal, they gain new capabilities, such as the ability to release growth factors and digestive enzymes. The cells continue to divide, impacting nearby normal cells, often reducing the function of the affected organ. Although not all cancers share exactly the same steps, there are some general features that are shared in the development of many types of cancer. Another critical step in the growth of a tumor is the development of a blood supply (angiogenesis). Blood provides nutrients, carries away waste and the blood vessels provide a way for cancer cells to move around the body. The genes that have been identified to date have been categorized into two broad categories, depending on their normal functions in the cell.

Genes whose protein products stimulate or enhance the division and viability of cells. This first category also includes genes that contribute to tumor growth by inhibiting cell death. The normal versions of these genes are called proto-oncogenes. The mutated or otherwise damaged versions of these genes are called oncogenes. Genes whose protein products can directly or indirectly prevent cell division or lead to cell death. The genes in these group are called tumor suppressor genes.

Multiple experimental evidences have confirmed that at the molecular level, cancer is due to defects in the cellular DNA. First, it has been observed that a cancer cell transmits to its daughter cells the phenotypic features characterizing the "cancerous" state. Second, most of the recognized mutagenic compounds are also carcinogenic, having as a target cellular DNA. Finally, the karyotyping of several types of human tumors, particularly those belonging to the hematopoietic system, led to the identification of recurrent qualitative and numerical chromosomal abberrations, reflecting pathologic re-arrangements of the cellular genome. Taken together, these observations suggest that the molecular pathogenesis of human cancer is due to structural and/or functional alterations of specific genes whose normal function is to control cellular growth and differentiation or, in different terms, cell birth and cell death.

The use of the DNA transfection technique that helped clarify the cellular origin of the "viral oncogenes." The latter were previously characterized as the specific genetic elements capable of conferring the tumorigenic properties to the RNA tumor viruses also known as retroviruses. Further, the transfection technique led to the identification of cellular transforming genes that do not have a viral counterpart. Besides the source of their original identification, viral or cellular genome, these transforming genetic elements have been designated as proto-oncogene in their normal physiologic version and oncogene when altered in cancer.

Advances in molecular studies had led to the identification of many oncogenes in cancer formation. This will help in early detection of many cancers. The action of drugs on oncogenes will help in specific treatment of different types of cancers. An overview of the functions, properties and clinical importance of oncogenes is discussed in the following sections. 


\section{The Cell Cycle}

Cell division is a physiological process that occurs in almost all tissues and under many circumstances. Under normal circumstances, the balance between proliferation and programmed cell death, usually in the form of apoptosis, is maintained by tightly regulating both processes to ensure the integrity of organs and tissues. ${ }^{1,2}$ Mutations in DNA that lead to cancer (only certain mutations can lead to cancer and the majority of potential mutations will have no bearing) disrupt these orderly processes by disrupting the programming regulating the processes.. This results in uncontrolled cell division and the evolution of those cells by natural selection in the body. The uncontrolled and often rapid proliferation of cells can lead to carcinogenesis. ${ }^{1}$

The four phases of a typical cell cycle of a eukaryotic cell are G1, $S_{G_{2}}$ and $M$ phase. G1, S and $G_{2}$ phases form the interphase, whilst the cell grows continuously ${ }^{3}$. Cell division occurs in $\mathrm{M}$ phase or the mitotic phase ( prophase, metaphase, anaphase and telophase). New synthesis of DNA is limited to S phase.G1 phase includes the period between $\mathrm{M}$ phase and $\mathrm{S}$ phase; $\mathrm{G}_{2}$ phase lies between $\mathrm{S}$ phase and $\mathrm{M}$ phase. ${ }^{4}$. The duration shown of $24 \mathrm{~h}$ is only approximate. There are cells with cell cycles of shorter or longer duration. ${ }^{2}$

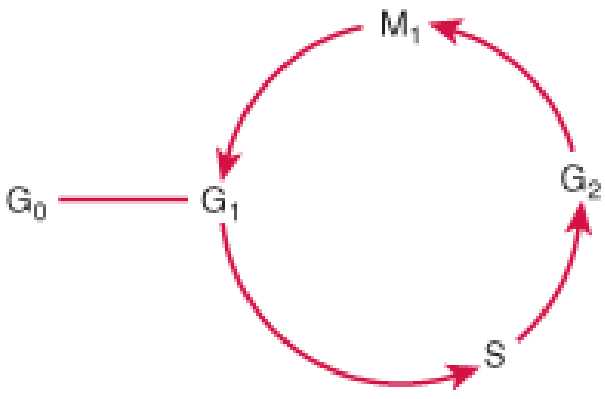

Fig:1-The Cell Cycle

The monitoring mechanisms register the completion of important cell cycle(e. g., complete DNA synthesis) and allows the transition to the next event. Entry into a new phase can occur only when the preceding phase has been completed. In addition, the coupling of processes that are not adjacent in the cell cycle sequence occurs. The close mutual regulation mechanisms between $\mathrm{M}$ and $\mathrm{S}$ phase have various control mechanisms. ${ }^{5}$

Many of the control mechanisms of the cell cycle are of an in turn constitutive, i. e., they are operational in every cell cycle and ensure the individual steps. However, other control mechanisms exist that are not at-cell cycle; these are only induced when defects are detected in cell. These control mechanisms are known as checkpoints or restriction point ${ }^{6}$. A checkpoint is a biochemical pathway that detects DNA damage and creates arrest in cycle progression or arrests cells in the $\mathrm{G}_{1,} \mathrm{~S}$ or $\mathrm{G} 2$ phase . $^{7,2}$

In addition to the built-in protection and control mechanisms, the cell is also subject to a number of external controls, which ensure that cell division occurs in balance with the overall development of the organism and with external growth conditions. This is an end of social control of cell division that regulates the progress of the cell cycle, with the help of circulating signal molecules or via cell-cell interactions. ${ }^{2}$

A biochemical system exists at the center of the cell cycle, of which the most important are the Ser/Thr-specific protein kinases and regulatory proteins associated with these. The activity of this central cell cycle apparatus regulates processes downstream that help to carry out the many phase-specific biochemical reactions of the cell cycle in a defined order.

Intrinsic control mechanisms ensure that the cycle is executed completely, so that, following cell division, both daughter cells are equipped with the same genetic information as far as possible. ${ }^{2}$ Of the many control mechanisms, the following are highlighted:

- Coupling of mitosis to a completed S phase: Mitosis is only initiated when the DNA has been completely replicated during $\mathrm{S}$ phase. Mechanisms must exist that register completion of $\mathrm{S}$ phase and couple this to entry into $M$ phase.

- Coupling of $\mathbf{S}$ phase and mitosis: Another control mechanism ensures that entry into $\mathrm{S}$ phase is only possible if preceded by mitosis. If the cell was able, during $G_{2}$ phase, to enter a new $S$ phase without mitosis taking place, this would lead to unprogrammed multiplication of the chromosome set and thus to polyploidy.

- Coupling of cell size and progress in G1phase: A further control mechanism, which is also intrinsic, tests whether signals in $M$ phase are large enough to initiate another round of cell division. The daughter cells produced by cell division must reach a critical size in the course of G1 phase before S phase can commence.

- DNA damage and the course of the cell cycle: The cellular genome is continually subject to damaging influences that may originate within the cell or externally. DNA damage must be repaired with the help of repair enzymes. Non repaired DNA damage leads to coding in DNA replication and thus to mutations. For this reason, the cell has control mechanisms that register DNA damage and may disrupt the cell cycle. 
Thus, there is time is gained for repair of DNA damage. The cells may all enter a resting state and may possibly initiate programmed cell death.

\section{Characteristics Of Tumour Cells}

Tumour cells have special features compared to normal cells. The phenotype of a tumour. Cell is characterized by the following characteristics:

1. Increased rate of cell division, loss of normal growth control

2. Loss of ability to differentiate

3. Loss of contact inhibition

4. Increased capability for invasion of neighboring tissue, metastasis.

The cells of a fully grown, aggressive tumour have acquired these properties in a slow, multi-step process with the characteristics of cellular evolution. ${ }^{5}$ This development is associated with a selection process, in the course of which, cells that have lost their growth-regulating mechanisms. The transition of a normal cell to a tumour cell can often be well characterized both morphologically and physiologically. However, only a few of the underlying biochemical changes are understood. ${ }^{8}$ Tumour cells differ from their progenitor cells in having acquired a large number of genetic changes. It is estimated that tumour cells accumulate several thousand to several hundred thousand changes in DNA sequence. ${ }^{9}$

\begin{tabular}{|l|l|}
\hline Gene & Function \\
\hline p14, 15 & CDK inhibitors \\
\hline PTEN & PdInsP $_{3}$ phosphatase \\
\hline MLH1 & DNA mismatch repair \\
\hline APC & Wnt signalling \\
\hline CDH-1 & Cell adhesion, loss during tumour metastasis \\
\hline NF1 & GAP involved in Ras signalling \\
\hline TIMP3 & Tissue inhibitor of metalloproteinase 3 \\
\hline BRCAl & DNA repair \\
\hline STK11 & Serine/threonine kinase 11, \\
\hline MGMT & DNA repair \\
\hline
\end{tabular}

Table 1:Genes that are frequently mutated and / or hypermethylated in cancer. ${ }^{2}$

\section{Causes Of Oncogenic Mutations}

Mutations that trigger and promote tumour formation may be caused by a number of processes. The following factors are involved:

\subsection{Intrinsic changes in the genetic information}

There are many endogenous processes that change the information content of the DNA. These processes are inseparable from the performance and characteristics of an organism, and they are influenced by external factors to only a small extent.

\subsubsection{DNA replication errors}

Replication of DNA does not occur with complete precision, but rather has an intrinsic inaccuracy. The error rate for incorporation of nucleotides in DNA replication is of the order of one error per $10^{6}-10^{8}$ correctly incorporated nucleotides. ${ }^{10}$

\subsubsection{Spontaneous DNA damage}

DNA has only limited stability in the temperature and $\mathrm{pH}$ conditions of an organism. Spontaneous changes in the DNA structure may occur, and cleavage of purine bases is considered to have an important role. The apurinic sites resulting from depurination may give rise to mutations if not repaired.

\subsubsection{Metabolism-related damage of DNA}

Reactive metabolic products are an important cause of endogenous damage to DNA. In the first place is reactive oxygen, which can lead to DNA damage, especially in the form of the superoxide anion $0_{2}$ - and in the form of $\mathrm{OH}$ radicals. Dietary components also include many chemical compounds with which can react. Furthermore, dietary components can be converted by metabolic activation into compounds with a high potential for damage to DNA. ${ }^{11}$ 


\subsection{External damage of DNA}

A number of external factors can lead to DNA damage and thus to mutations. These include especially the effects of carcinogenic chemicals and UV, X-ray, and other high-energy radiation (e.g., radioactivity).

\subsection{Viruses}

There are a large number of RNA- or DNA-viruses that are directly associated with tumour formation.

Three principal mechanisms are responsible

- Introduction of viral oncogenes into the host genome

- Interaction with virus-specific proteins and signal proteins of the host cell

- Control of expression of proto-oncogenes by a viral promoter.

\section{Oncogenes And Proto-Oncogenes}

Oncogenes are genes that can result in a transforming or immortalizing phenotype on experimental transformation in cellular model systems. Oncogenes arise by activating mutation of their precursors, the protooncogenes. Proto-oncogenes are often directly involved in growth regulation of normal cells. Oncogenes generally have dominant character. The mutation of a proto-oncogene to an oncogene is phenotypically visible when only one of the two copies of the gene in a diploid chromosome set is affected by the mutation. The dominant mutation is accompanied by a "gain of junction"; it typically amplifies or increases the yield of a function in growth regulation. ${ }^{12,13,14,15}$

The first oncogene was discovered in 1970 and was termed src (pronounced sarc as in sarcoma). Src was in fact first discovered as an oncogene in a chicken retrovirus. Experiments performed by Dr G. Steve Martin of the University of California, Berkeley demonstrated that the SRC was indeed the oncogene of the virus. $^{16}$

In 1976 Drs. J. Michael Bishop and Harold E. Varmus of the University of California, San Francisco demonstrated that oncogenes were defective proto-oncogenes, found in many organisms including humans. For this discovery Bishop and Varmus were awarded the Nobel Prize in 1989. ${ }^{17,18,19}$

The term oncogene was coined in association with the search for the tumour-causing principle in retroviruses. Retroviruses contain RNA as the genetic material and can transcribe RNA into DNA with the help of the virus's own enzyme reverse transcriptase. The DNA form of retroviruses can integrate into the DNA of the host cell and, during cell division, is passed on to the daughter cells as a provirus. From the provirus, viral RNA and complete virus particles may be formed..$^{20,21,22}$

The discovery of oncogenes followed the investigation of the src gene of Rat sarcoma virus, which could be identified as the tumour-causing principle of this retrovirus. The src gene codes for the Src tyrosine kinase. The gene sections of retroviruses responsible for tumour formation were designated oncogenes.Soon after discovery of the oncogene, it was demonstrated that the viral oncogenes are mutated forms of the genes of cellular proteins that are also active in normal cells. The cellular variants of viral oncogenes were named protooncogenes. The oncogenes of retroviruses are prefixed with a ' $v$ ' (e.g., v-src, v-sis), whereas the corresponding proto-oncogenes are prefixed with a 'c' (e.g., c-src, c-sis).

Generally the function of oncogenes during multistep carcinogenesis is considered to reside in a growth advantage that is conferred by the altered function of the proto-oncogene product. The affected cells are no longer subject to the normal growth control that is exerted by a finely balanced network of mitogenic and antimitogenic signals. Therefore, cells harboring oncogenes proliferate preferentially and autonomously and help to expand the pool of mutated cells that is the target of selection during tumorigenesis. ${ }^{23,24,25}$

It should be pointed out that the oncogenic function of a particular gene is generally defined via cellular model systems which use primary cell lines or immortalized cell lines. The multistep nature of tumour formation is not considered in the cellular model systems. ${ }^{27,28,29}$

\section{Evidence of Somatic Genetic Change}

The first evidence that cancer arises from somatic genetic alterations came from studies of Burkitt's lymphoma, in which one of three different translocations juxtaposes an oncogene, $M Y C$, on chromosome 8q24 to one of the loci for immunoglobulin genes. Chromosomes 14q, 22q, and $2 p-$ the translocation partners each carries enhancer elements in the immunoglobulin loci, thereby activating the juxtaposed $M Y C$ oncogene ${ }^{15}$, ${ }^{20,21}$ Since every malignant lymphocyte carries the $M Y C$ translocation, deregulation of the MYC oncogene is probably the initiating event.

Second, transfection experiments have shown that mouse fibroblasts, when transfected in vitro with DNA from human cancer cells, acquire some of the properties of malignant cells (i.e., transformation). The transforming activity of the DNA was traced to a human homologue of the retroviral RAS oncogene. This oncogene bears mutations that activate the transforming property of the RAS oncogenic protein ${ }^{22,23}$ 
Third, the cloning and characterization of the chromosomal breakpoints that are characteristic of follicular lymphomas and some diffuse large B-cell lymphomas have shown a juxtaposition of the $B C L 2$ oncogene to enhancer elements in the immunoglobulin heavy-chain locus, resulting in deregulation of $B C L 2^{24,25,26}$

Fourth, in transgenic mice that carry an activated oncogene from a human tumor, cancers develop that resemble the human tumor. ${ }^{17,28,29}$ That these cancers appear only after a latent period suggests that alterations in other genes must occur before progression to frank neoplasia can occur - activation of a particular oncogene seems to be necessary but not sufficient for the development of overt cancer.

\section{Mechanisms Of Activation Of Proto-Oncogenes}

The activation of a proto-oncogene to an oncogene is based on mutations that can change the function and regulation of the affected protein by various mechanisms. Two pathways of activation can be roughly differentiated. On the one hand, the structure of the coded protein may be affected; on the other hand, activation may lead to a concentration increase in the protein.

\subsection{Activation by Structural Changes}

A frequent cause of activation of proto-oncogenes is a change in the structure of the coded protein, affecting the regulation and function. Via the oncogenic activation, there is no creation of completely new functions, but rather the normal function of a proto-oncogene product is modified and/or released from cellular regulation. ${ }^{2}$ The spectrum of structural mutations that can convert a proto-oncogene into an oncogene is very diverse. Both simple amino acid changes and larger structural changes are observed in the coded protein. In particular, viral oncoproteins demonstrate multiple mutations compared to their cellular counterparts, linked to important and far-reaching structural and functional changes.

Proto-oncogenes may be converted into oncogenes via the concentration increase pathway or the structural change pathway. In the case of the concentration increase, there is an excessive and unprogrammed function of the signal protein coded by the proto-oncogene. In the case of structural change, the proliferationpromoting activity of the oncoprotein results from changed activity, altered regulation or formation of a hybrid protein. $^{2}$

\subsection{Increase in Activity of Signal Proteins}

Activating point mutations may directly affect the enzyme activity of a signal protein. The mechanism of activating oncogenic point mutations is best documented for the Ras protein. Many of the point mutations at positions 12 and 13 of the Ras protein, which are also observed in solid tumours, bring about a reduction in the rate of GTP hydrolysis. This can no longer be increased by the GAP protein,, so that the active GTP state exists for a longer duration. It is assumed that this is the cause of unprogrammed stimulation of the Ras-MAPK pathway, which is manifested as increased cell division activity and leads to a growth advantage of the affected cell. $^{2}$

\subsection{Change in the Regulation of Signal Proteins}

Mutations may lead to loss of cellular control over the activity of a proto-oncogene. Frequently, this brings about constitutive activation of the signal protein. Thus, in the transforming v-raf gene, the N-terminal sequence section of Raf kinase is missing, on which both the autoinhibitory function and the phosphorylation sites of Raf kinase are localized. ${ }^{2}$

\subsection{Formation of Hybrid Proteins}

In many tumours, a reciprocal exchange of DNA sections on different chromosomes is observed. During this translocation of chromosomes, gene fusions may occur, leading, to the formation of chimeric proteins. Within the chimeric proteins, there are often structural portions that originate from signal proteins. The function of the signal protein portion is removed from normal regulation in the chimeric protein and can have a tumour-promoting effect. Tyrosine kinases and transcription factors are often affected by gene fusions. The chimeric proteins arising from chromosome translocation frequently represent a characteristic of a particular tumour type ${ }^{2}$

\subsection{Activation by Concentration Increase}

A change in the gene expression or stability of a proto-oncogene product may lead to an increase in the cellular concentration of the protein. Because of the increased concentration, a mitogenic signal mediated by a proto-oncogene product may be amplified. ${ }^{2}$ 


\subsection{Over-expression of Proto-oncogenes}

The over-expression of proliferation-regulating proteins may lead to immortalization and/or transformation in cellular model systems. Over-expression of signal proteins is observed in many tumours, and it is assumed that the over-expression is associated with pathogenesis of the tumour. The mechanisms leading to over-expression are diverse and theoretically include all processes involved in expression regulation. Of note are translocations of a proto-oncogene into the vicinity of a strong promoter, causing excessive or deregulated expression of the corresponding gene. ${ }^{2}$

Activation of proto-oncogenes by unprogrammed expression is often associated with chromosome translocations in leukemias and lymphomas. In Burkitt's lymphoma, different translocations of the c-myc gene, which codes for the c-Myc transcription factor, are found. The translocations bring about movement of the cmyc gene intothe vicinity of immunoglobulin genes. Consequently, constitutive expression of thec-Myc protein occurs, disturbing the normal regulatory network into which the c-Myc protein is bound.

Another tumour-promoting mechanism based on deregulation of transcription of growth factors is the formation of autocrine loops. In the course of tumour formation, unprogrammed expression of growth factors may occur in cells in which there would normally be little or no expression of these proteins. If these cells express the appropriate growth factor receptors, the growth factors may bind to these and create a stimulus of division. The cell is no longer dependent on the supply of an external growth factor. The cell then produces its own growth factor and division stimulus.

\section{Oncogene Activation}

Activation of oncogenes by chromosomal rearrangements, mutations, and gene amplification confers a growth advantage or increased survival of cells carrying such alterations. All three mechanisms cause either an alteration in the oncogene structure or an increase in or deregulation of its expression. ${ }^{30}$

\subsection{Chromosomal Rearrangements}

Chromosome inversions and translocations are common cytogenetic abnormalities in cancer cells. In hematopoietic cancers and solid tumors, the translocations and inversions increase or deregulate transcription of the oncogene. In prostate cancer, gene fusion occurs between a gene that carries a promoter that is very active in the target cells, and another that carries the oncogenic activity (e.g., ERGI) ${ }^{31}$. In cancers of B and T cells, the most common mechanism of activation by translocation resembles MYC deregulation, whereas in myeloid cancers and soft-tissue sarcomas, gene fusion is more common.

\subsection{Mutations}

When an oncogene is activated by mutation, the structure of the encoded protein is changed in a way that enhances its transforming activity. Many types of mutation occur in oncogenes ${ }^{32}$. Examples are the $R A S$ oncogenes (KRAS, HRAS, and NRAS), which encode proteins with guanosine-nucleotide-binding activity and intrinsic guanosine triphosphatase activity. When mutated in codon 12,13 , or 61 , the $R A S$ genes encode a protein that remains in the active state and continuously transduces signals by linking tyrosine kinases to downstream serine and threonine kinases. These incessant signals induce continuous cell growth. Mutation of oncogenes in the RAS family has been associated with exposure to environmental carcinogens. Mutations of $K R A S$ are common in carcinomas of the lung, colon, and pancreas, ${ }^{32}$ whereas mutations of NRAS occur principally in acute myelogenous leukemia and the myelodysplastic syndrome. ${ }^{33}$

Activating point mutations of the BRAF gene occur in $59 \%$ of melanomas, $18 \%$ of colorectal cancers, $14 \%$ of hepatocellular carcinomas, and $11 \%$ of gliomas. ${ }^{34}$ Most of the BRAF mutations change the valine residue at position 599 to glutamic acid (V599E). This change occurs within the kinase domain of the BRAF protein, resulting in a constitutively active protein that uncontrollably stimulates the MAP kinase cascade, thereby deregulating genes involved in cell proliferation, differentiation, and survival. ${ }^{34,35} \mathrm{In}$ melanoma, $B R A F$ mutations can precede neoplastic transformation; several types of nevi carry $B R A F$ mutations.

\subsection{Gene Amplification}

An example of gene amplification, which usually occurs during tumor progression, is the amplification of the dihydrofolate reductase gene $(D H F R)$ in methotrexate-resistant acute lymphoblastic leukaemia. ${ }^{36}$ Amplification of DHFR is accompanied by cytogenetic alterations that mirror amplification of Oncogenes. ${ }^{37,38}$ The amplified DNA segment usually involves several hundred kilobases and can contain many genes. Members of four different oncogene families are often amplified: MYC, cyclin D1 (or CCND1), EGFR, and RAS. MYC is amplified in small-cell lung cancer, breast cancer, esophageal cancer, cervical cancer, ovarian cancer, and head and neck cancer, whereas amplification of $N M Y C$ correlates with an advanced tumor stage. ${ }^{39}$ The $t(11 ; 14)$ translocation juxtaposes $C C N D 1$ and immunoglobulin enhancer elements and is characteristic of mantle-cell lymphoma. ${ }^{25}$ CCND1 amplification also occurs in breast, esophageal, hepatocellular, and head and neck cancer. 
$E G F R(E R B B 1)$ is amplified in glioblastoma and head and neck cancer. Amplification of ERBB2 (also called $H E R 2 / n e u$ ) in breast cancer correlates with a poor prognosis. ${ }^{40} \mathrm{~A}$ monoclonal antibody against the product of this oncogene (trastuzumab) is effective in breast cancers that over-express HER2/neu.

\section{Functional Classification Of Oncogenes}

More than 100 dominant oncogenes have been identified to date. Nearly all the components of the signal transduction chains that transmit signals from the cell exterior to the level of the cell cycle and transcription can be converted by mutations into an oncogenic state. It has to be emphasized that activation of an oncogene is generally not sufficient for transformation of a normal cell into a tumour cell. Functional inactivation of cell death mechanisms must occur at the same time, and it is the cooperation of defects in oncogenic pathways and in apoptotic pathways that paves the way for the formation of a real tumour.

Table 2: Functional classification of oncogenes. ${ }^{18,41-57}$

\begin{tabular}{|c|c|c|c|c|c|}
\hline $\begin{array}{l}\text { Oncoge } \\
\text { ne }\end{array}$ & $\begin{array}{l}\text { Chromoso } \\
\text { me }\end{array}$ & $\begin{array}{l}\text { Method of } \\
\text { Identification }\end{array}$ & Neoplasm & $\begin{array}{l}\text { Mechanism of } \\
\text { Activation }\end{array}$ & $\begin{array}{l}\text { Protein } \\
\text { Function }\end{array}$ \\
\hline \multicolumn{6}{|c|}{ Growth factors } \\
\hline $\mathrm{v}$-sis & $\begin{array}{l}22 q 12.3 \\
-13.1 \\
\end{array}$ & $\begin{array}{l}\text { Sequence } \\
\text { homology }\end{array}$ & $\begin{array}{l}\text { Glioma/ } \\
\text { fibrosarcoma }\end{array}$ & $\begin{array}{l}\text { Constitutive } \\
\text { production }\end{array}$ & B chain PDGF \\
\hline Int2 & $11 \mathrm{q} 13$ & $\begin{array}{l}\text { Proviral } \\
\text { insertion }\end{array}$ & $\begin{array}{l}\text { Mammary } \\
\text { carcinoma }\end{array}$ & $\begin{array}{l}\text { Constitutive } \\
\text { production }\end{array}$ & $\begin{array}{l}\text { Member of FGF } \\
\text { family }\end{array}$ \\
\hline KS3 & $11 \mathrm{q} 13.3$ & $\begin{array}{l}\text { DNA } \\
\text { transfection }\end{array}$ & $\begin{array}{l}\text { Kaposi's } \\
\text { sarcoma }\end{array}$ & $\begin{array}{l}\text { Constitutive } \\
\text { production }\end{array}$ & $\begin{array}{l}\text { Member of FGF } \\
\text { family }\end{array}$ \\
\hline HST & $11 \mathrm{q} 13.3$ & $\begin{array}{l}\text { DNA } \\
\text { transfection }\end{array}$ & $\begin{array}{l}\text { Stomach } \\
\text { carcinoma }\end{array}$ & $\begin{array}{l}\text { Constitutive } \\
\text { production }\end{array}$ & $\begin{array}{l}\text { Member of FGF } \\
\text { family }\end{array}$ \\
\hline \multicolumn{6}{|c|}{ Growth factors receptors } \\
\hline \multicolumn{6}{|c|}{ Tyrosine kinases: integral membrane proteins } \\
\hline EGFR & $\begin{array}{l}7 \mathrm{p} 1.1- \\
1.3\end{array}$ & $\begin{array}{l}\text { DNA } \\
\text { amplificatio }\end{array}$ & $\begin{array}{l}\text { Squamous cell } \\
\text { carcinoma }\end{array}$ & $\begin{array}{l}\text { Gene } \\
\text { amplification/incre } \\
\text { ased }\end{array}$ & EGF receptor \\
\hline$v-f m s$ & $\begin{array}{l}5 \mathrm{q} 33-34 \\
\text { (FMS) }\end{array}$ & Viral homologue & Sarcoma & $\begin{array}{l}\text { Constitutive } \\
\text { activation }\end{array}$ & CSF1 receptor \\
\hline v-kit & $\begin{array}{l}4 \mathrm{q} 11-21 \\
\text { (KIT) }\end{array}$ & Viral homologue & Sarcoma & $\begin{array}{l}\text { Constitutive } \\
\text { activation }\end{array}$ & $\begin{array}{l}\text { Stem cell Factor } \\
\text { receptor }\end{array}$ \\
\hline v-ros & $\begin{array}{l}6 \mathrm{q} 22 \\
\text { (ROS) }\end{array}$ & Viral homologue & Sarcoma & $\begin{array}{l}\text { Constitutive } \\
\text { activation }\end{array}$ & 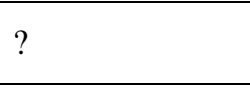 \\
\hline MET & $7 \mathrm{p} 31$ & $\begin{array}{l}\text { DNA } \\
\text { transfection }\end{array}$ & $\begin{array}{l}\text { MNNG-treated } \\
\text { human } \\
\text { osteocarcinoma } \\
\text { cell line } \\
\end{array}$ & $\begin{array}{l}\text { DNARe-arrangement/ } \\
\text { ligand- inde-pendent } \\
\text { constitutive acti- } \\
\text { vation(fusion proteins) }\end{array}$ & $\begin{array}{l}\text { HGF/SF } \\
\text { receptor }\end{array}$ \\
\hline TRK & $1 q 32-41$ & $\begin{array}{l}\text { DNA } \\
\text { transfection }\end{array}$ & $\begin{array}{l}\text { Colon/ thyroid } \\
\text { carcinomas }\end{array}$ & $\begin{array}{l}\text { DNARe-arrangement/ } \\
\text { ligand- inde-pendent } \\
\text { constitutive acti- } \\
\text { vation(fusion proteins) }\end{array}$ & NGF receptor \\
\hline NEU & $\begin{array}{l}17 \mathrm{q} 11.2 \\
-12\end{array}$ & $\begin{array}{l}\text { Point mutation/ } \\
\text { DNA } \\
\text { amplification }\end{array}$ & $\begin{array}{l}\text { Neuroblastoma/ } \\
\text { breast } \\
\text { carcinoma }\end{array}$ & Gene amplification & $?$ \\
\hline RET & $10 \mathrm{q} 11.2$ & $\begin{array}{l}\text { DNA } \\
\text { transfection }\end{array}$ & $\begin{array}{l}\text { Carcinomas of } \\
\text { thyroid Men } \\
\text { 2A. Men 2B }\end{array}$ & $\begin{array}{l}\text { DNA Rearrange- } \\
\text { ment/pointmutation } \\
\text { (ligand-ndependent } \\
\text { constitutiveactivati } \\
\text { on/ fusion proteins) }\end{array}$ & $\begin{array}{l}\text { GDNF/NTT/AR } \\
\text { T/PSP receptor }\end{array}$ \\
\hline \multicolumn{6}{|c|}{ Receptors lacking protein kinase activity } \\
\hline Mas & $6 q 24-27$ & $\begin{array}{l}\text { DNA } \\
\text { transfection }\end{array}$ & $\begin{array}{l}\text { Epidermoid } \\
\text { carcinoma }\end{array}$ & $\begin{array}{l}\text { Rearrangment of } \\
\text { 5'non-codingregion }\end{array}$ & $\begin{array}{l}\text { Angiotensin } \\
\text { receptor }\end{array}$ \\
\hline \multicolumn{6}{|c|}{ Signal transducers } \\
\hline
\end{tabular}


Oncogenes as Therapeutic Targets in Cancer: A Review

\begin{tabular}{|c|c|c|c|c|c|}
\hline SRC & $20 \mathrm{p} 12-13$ & $\begin{array}{l}\text { Viral } \\
\text { homolog }\end{array}$ & $\begin{array}{l}\text { Colon } \\
\text { carcinoma }\end{array}$ & $\begin{array}{l}\text { Constitutive } \\
\text { activation }\end{array}$ & $\begin{array}{l}\text { Protein tyrosine } \\
\text { kinase }\end{array}$ \\
\hline v-yes & $\begin{array}{l}18 \mathrm{q} 21-3 \\
(\mathrm{YES})\end{array}$ & $\begin{array}{l}\text { Viral } \\
\text { homolog }\end{array}$ & Sarcoma & $\begin{array}{l}\text { Constitutive } \\
\text { activation }\end{array}$ & $\begin{array}{l}\text { Protein tyrosine } \\
\text { kinase }\end{array}$ \\
\hline v-fgr & $\begin{array}{l}\text { 1p36.1- } \\
36.2 \text { (FGR) }\end{array}$ & $\begin{array}{l}\text { Viral } \\
\text { homolog }\end{array}$ & Sarcoma & $\begin{array}{l}\text { Constitutive } \\
\text { activation }\end{array}$ & $\begin{array}{l}\text { Protein tyrosine } \\
\text { kinase }\end{array}$ \\
\hline v-fes & $\begin{array}{l}15 q 25-26 \\
\text { (FES) }\end{array}$ & $\begin{array}{l}\text { Viral } \\
\text { homolog }\end{array}$ & Sarcoma & $\begin{array}{l}\text { Constitutive } \\
\text { activation }\end{array}$ & $\begin{array}{l}\text { Protein tyrosine } \\
\text { kinase }\end{array}$ \\
\hline $\mathrm{ABL}$ & $9 q 34.1$ & $\begin{array}{l}\text { Chromosome } \\
\text { translocation }\end{array}$ & CML & $\begin{array}{l}\text { DNA Re- } \\
\text { arrangement } \\
\text { (constitutive } \\
\text { activation/ fusion } \\
\text { proteins) }\end{array}$ & $\begin{array}{l}\text { Protein tyrosine } \\
\text { kinase }\end{array}$ \\
\hline \multicolumn{6}{|c|}{ Membrane-associated $\mathrm{G}$ proteins } \\
\hline H-RAS & $11 \mathrm{p} 15.5$ & $\begin{array}{l}\text { Viral } \\
\text { homolog/DN } \\
\text { A transfection }\end{array}$ & $\begin{array}{l}\text { Colon, lung, } \\
\text { pancreas } \\
\text { carcinomas }\end{array}$ & Point mutation & GTPase \\
\hline K-RAS & $\begin{array}{l}12 \mathrm{p} 11.1- \\
12.1\end{array}$ & $\begin{array}{l}\text { Viral } \\
\text { homolog/DN } \\
\text { A transfection } \\
\end{array}$ & $\begin{array}{l}\text { AML, thyroid } \\
\text { carcinoma,mela } \\
\text { noma }\end{array}$ & Point mutation & GTPase \\
\hline N-RAS & $1 \mathrm{p} 11-13$ & $\begin{array}{l}\text { DNA } \\
\text { transfection }\end{array}$ & $\begin{array}{l}\text { Carcinoma, } \\
\text { melanoma }\end{array}$ & Point mutation & GTPase \\
\hline Gsp & 20 & $\begin{array}{l}\text { DNA } \\
\text { sequencing }\end{array}$ & $\begin{array}{l}\text { Adenomas of } \\
\text { thyroid }\end{array}$ & Point mutation & Gs alpha \\
\hline Gip & 3 & $\begin{array}{l}\text { DNA } \\
\text { sequencing }\end{array}$ & $\begin{array}{l}\text { Ovary, adrenal } \\
\text { carcinoma }\end{array}$ & Point mutation & Gi alpha \\
\hline \multicolumn{6}{|c|}{ GTPase exchange factor (GEF) } \\
\hline $\mathrm{Dbl}$ & $\mathrm{Xq} 27$ & $\begin{array}{l}\text { DNA } \\
\text { transfection }\end{array}$ & $\begin{array}{l}\text { Diffuse B-cell } \\
\text { lymphoma }\end{array}$ & $\begin{array}{ll}\text { DNA } & \text { Re- } \\
\text { arrangement } & \\
\end{array}$ & $\begin{array}{l}\text { GEF for Rho } \\
\text { and } \mathrm{Cdc} 42 \mathrm{Hs}\end{array}$ \\
\hline Vav & $19 \mathrm{p} 13.2$ & $\begin{array}{l}\text { DNA } \\
\text { transfection }\end{array}$ & $\begin{array}{l}\text { Hematopoietic } \\
\text { cells }\end{array}$ & $\begin{array}{l}\text { DNA } \\
\text { Rearrangement }\end{array}$ & GEF for Ras? \\
\hline \multicolumn{6}{|c|}{ Serine/threonine kinases: cytoplasmic } \\
\hline v-mos & $\begin{array}{l}8 \mathrm{q} 11 \\
(\mathrm{MOS})\end{array}$ & Viral homolog & Sarcoma & $\begin{array}{l}\text { Constitutive } \\
\text { activation }\end{array}$ & $\begin{array}{ll}\begin{array}{l}\text { Protein } \\
(\text { ser/thr })\end{array} & \\
\end{array}$ \\
\hline v-raf & $\begin{array}{l}3 \mathrm{p} 25 \\
\text { (RAF-1) }\end{array}$ & Viral homolog & Sarcoma & $\begin{array}{l}\text { Constitutive } \\
\text { activation }\end{array}$ & $\begin{array}{ll}\begin{array}{l}\text { Protein } \\
\text { (ser/thr) }\end{array} & \text { kinase } \\
\end{array}$ \\
\hline Pim-1 & $\begin{array}{l}\text { 6p21 } \\
\text { (PIM-) }\end{array}$ & $\begin{array}{l}\text { Insertional } \\
\text { mutagenesis }\end{array}$ & $\begin{array}{l}\text { T-cell } \\
\text { lymphoma }\end{array}$ & $\begin{array}{l}\text { Constitutive } \\
\text { activation }\end{array}$ & $\begin{array}{ll}\begin{array}{l}\text { Protein } \\
\text { (ser/thr) }\end{array} & \text { kinase } \\
\end{array}$ \\
\hline \multicolumn{6}{|c|}{ Cytoplasmic regulators } \\
\hline v-crk & $\begin{array}{l}17 \mathrm{p} 13 \\
(\mathrm{CRK})\end{array}$ & $\begin{array}{l}\text { Viral } \\
\text { homologue }\end{array}$ & & $\begin{array}{l}\text { nstitutive tyrosine } \\
\text { osphorilation of cel- } \\
\text { ar substrates (e.g., } \\
\text { xillin) }\end{array}$ & $\begin{array}{l}\mathrm{SH}-2 / \mathrm{SH}-3 \\
\text { adaptor }\end{array}$ \\
\hline \multicolumn{6}{|c|}{ Trancription Factors } \\
\hline v-myc & $\begin{array}{l}8 \mathrm{q} 24.1 \\
(\mathrm{MYC})\end{array}$ & $\begin{array}{l}\text { Viral } \\
\text { homologue }\end{array}$ & $\begin{array}{l}\text { Carcinoma } \\
\text { myelocytoma- } \\
\text { tosis }\end{array}$ & $\begin{array}{l}\text { Deregulated } \\
\text { activity }\end{array}$ & $\begin{array}{l}\text { Transcription } \\
\text { factor }\end{array}$ \\
\hline N-MYC & $2 \mathrm{p} 24$ & $\begin{array}{l}\text { DNA } \\
\text { amplification }\end{array}$ & $\begin{array}{l}\text { Neuroblastoma } \\
: \quad \text { lung } \\
\text { carcinoma }\end{array}$ & $\begin{array}{l}\text { Deregulated } \\
\text { activity }\end{array}$ & $\begin{array}{l}\text { Transcription } \\
\text { factor }\end{array}$ \\
\hline L-MYC & $1 \mathrm{p} 32$ & $\begin{array}{l}\text { DNA } \\
\text { amplification }\end{array}$ & $\begin{array}{l}\text { Carcinoma of } \\
\text { lung }\end{array}$ & $\begin{array}{l}\text { Deregulated } \\
\text { activity }\end{array}$ & $\begin{array}{l}\text { Transcription } \\
\text { factor }\end{array}$ \\
\hline$v-m y b$ & $6 q 22-24$ & $\begin{array}{l}\text { Viral } \\
\text { homologue }\end{array}$ & Myeloblastosis & $\begin{array}{l}\text { Deregulated } \\
\text { activity }\end{array}$ & $\begin{array}{l}\text { Transcription } \\
\text { factor }\end{array}$ \\
\hline$v-f o s$ & $14 q 21-22$ & $\begin{array}{l}\text { Viral } \\
\text { homologue }\end{array}$ & Osteosarcoma & $\begin{array}{l}\text { Deregulated } \\
\text { activity }\end{array}$ & $\begin{array}{l}\text { Transcription factor } \\
\text { API }\end{array}$ \\
\hline$v$-jun & p31-32 & $\begin{array}{l}\text { Viral } \\
\text { homologue }\end{array}$ & Sarcoma & $\begin{array}{l}\text { Deregulated } \\
\text { activity }\end{array}$ & $\begin{array}{l}\text { Transcription } \\
\text { factor API }\end{array}$ \\
\hline
\end{tabular}


Oncogenes as Therapeutic Targets in Cancer: A Review

\begin{tabular}{|c|c|c|c|c|c|}
\hline v-ski & $1 q 22-24$ & $\begin{array}{l}\text { Viral } \\
\text { homologue }\end{array}$ & Carcinoma & $\begin{array}{l}\text { Deregulated } \\
\text { activity }\end{array}$ & $\begin{array}{l}\text { Transcription } \\
\text { factor }\end{array}$ \\
\hline v-rel & $2 \mathrm{p} 12-14$ & $\begin{array}{l}\text { Viral } \\
\text { homologue }\end{array}$ & $\begin{array}{l}\text { Lymphatic } \\
\text { leukemia }\end{array}$ & $\begin{array}{l}\text { Deregulated } \\
\text { activity }\end{array}$ & Mutant NFKB \\
\hline v-ets-1 & $11 \mathrm{p} 23-\mathrm{q} 24$ & $\begin{array}{l}\text { Viral } \\
\text { homologue }\end{array}$ & $\begin{array}{l}\text { Erythroblasto- } \\
\text { sis }\end{array}$ & $\begin{array}{l}\text { Deregulated } \\
\text { activity }\end{array}$ & $\begin{array}{l}\text { Transcription } \\
\text { factor }\end{array}$ \\
\hline v-ets-2 & $21 q 24.3$ & $\begin{array}{l}\text { Viral } \\
\text { homologue }\end{array}$ & $\begin{array}{l}\text { Erythroblasto- } \\
\text { sis }\end{array}$ & $\begin{array}{l}\text { Deregulated } \\
\text { activity }\end{array}$ & $\begin{array}{l}\text { Transcription } \\
\text { factor }\end{array}$ \\
\hline v-erbA1 & $17 \mathrm{p} 11-21$ & $\begin{array}{l}\text { Viral } \\
\text { homologue }\end{array}$ & $\begin{array}{l}\text { Erythroblasto- } \\
\text { sis }\end{array}$ & $\begin{array}{l}\text { Deregulated } \\
\text { activity }\end{array}$ & $\begin{array}{l}\text { T3 Transcription } \\
\text { factor }\end{array}$ \\
\hline v-erbA2 & $3 \mathrm{p} 22-24.1$ & $\begin{array}{l}\text { Viral } \\
\text { homologue }\end{array}$ & $\begin{array}{l}\text { Erythroblastosi } \\
\mathrm{s}\end{array}$ & $\begin{array}{l}\text { Deregulated } \\
\text { activity }\end{array}$ & $\begin{array}{l}\text { T3 Transcription } \\
\text { factor }\end{array}$ \\
\hline \multicolumn{6}{|l|}{ Others } \\
\hline BCL2 & $18 \mathrm{q} 21.3$ & $\begin{array}{l}\text { Chromosomal } \\
\text { translocation }\end{array}$ & $\begin{array}{l}\text { B-cell } \\
\text { lymphomas }\end{array}$ & $\begin{array}{l}\text { Constitutive } \\
\text { activity }\end{array}$ & $\begin{array}{l}\text { Antiapoptotic } \\
\text { protein }\end{array}$ \\
\hline MDM2 & $12 q 14$ & $\begin{array}{l}\text { DNA } \\
\text { amplification }\end{array}$ & Sarcomas & $\begin{array}{l}\text { Gene } \\
\text { amplification/incre } \\
\text { ased protein }\end{array}$ & $\begin{array}{l}\text { Complexes with } \\
\text { p53 }\end{array}$ \\
\hline
\end{tabular}

$\mathrm{AML}=$ acute myeloid leukemia; $\mathrm{CML}=$ chronic myelogenous leukemia; GTPase = guanosine triphosphatase; $\mathrm{PDGF}=$ platelet-derived growth factor.

\section{Cancer therapies that target Oncogenic proteins.}

Oncogenic proteins in cancer cells can be targeted by small molecules and, when the oncogenic protein is expressed on the cell surface, by monoclonal antibodies. Table 3 contains a summary of the targets and drugs (small molecules and monoclonal antibodies) being used in the treatment of a variety of human cancers. Imatinib targets the initial step of the multistep process in chronic myelogenous leukaemia. The same drug can affect the KIT and PDGFR receptor kinases. Of particular interest are inhibitors of the BCL2 family, which can induce the apoptotic death of cancer cells. In acute promyelocytic leukemia, which is initiated by a $t(15 ; 17)$

chromosometranslocation that fuses the $P M L$ gene to $R A R$ (a nuclear receptor for retinoic acids; retinoic acid can induce terminal differentiation and death of APL cells. This modality is called differentiation therapy.

Table 3:Cancer therapies that target Oncogenic proteins. ${ }^{16,18,41}$

\begin{tabular}{|l|l|l|}
\hline Anticancer drug & Target & Disesase \\
\hline 1.Monoclonal antibodies & Breast cancer \\
\hline $\begin{array}{l}\text { Trastumab(Herceptin, } \\
\text { Genentech) }\end{array}$ & ERBB2 & Colorectal cancer \\
\hline Cetuximab(Erbitux,ImClone) & EGFR & $\begin{array}{l}\text { Colorectal cancer, } \\
\text { Non-small cell lung cancer }\end{array}$ \\
\hline $\begin{array}{l}\text { Bevacizumab(Avastin, } \\
\text { Genentech) }\end{array}$ & VEGF & $\begin{array}{l}\text { Myelogenous } \\
\text { 2. Small molecules }\end{array}$ \\
\hline Imitinib(Gleevec,Novartis) & ABL,PDGFR,KIT & $\begin{array}{l}\text { Chronic cukaemia,gastrointestinal } \\
\text { stromal tumors, chordoma. }\end{array}$ \\
\hline Gefitinib(Iressa, AstraZeneca) & EGFR & Non-small cell lung cancer \\
\hline $\begin{array}{l}\text { Erlotinib(Tarceva, } \\
\text { Genentech) }\end{array}$ & EGFR & Non-small cell lung cancer \\
\hline $\begin{array}{l}\text { Sorafenib(Nexavar, } \\
\text { Bayer/Onyx) }\end{array}$ & VEGFR,PDGFR,FLT3 & Renal cell carcinoma \\
\hline Sunitinib(Sutent, Pfizer) & VEGFR,PDGFR,FLT3 & $\begin{array}{l}\text { Gastrointestinal stromal } \\
\text { tumors, Renal cell carcinoma }\end{array}$ \\
\hline
\end{tabular}

EGFR-epidermal growth factor receptor, FLT3-FMS-like tyrosine kinase 3, PDGFR-platelet derived growth factor receptor and VEGF- vascular endothelial growth factor. 


\section{Conclusion}

The discovery of oncogenes represented a breakthrough for our understanding of the molecular and genetic basis of cancer. Oncogenes have also provided important knowledge concerning the regulation of normal cell proliferation, differentiation, and programmed cell death. The identification of oncogene abnormalities has provided tools for the molecular diagnosis and monitoring of cancer. Most important, oncogenes represent potential targets for new types of cancer therapies. It is more than a hope that a new generation of chemotherapeutic agents directed at specific oncogene targets will be developed. The goal of these new drugs will be to kill cancer cells selectively while sparing normal cells. One promising approach entails using specific oncogene targets to trigger programmed cell death. Our rapidly expanding knowledge of the molecular mechanisms of cancer holds great promise for the development of better combined methods of cancer therapy in the near future.

\section{REFERENCES}

[1]. Fearon, E.R., Vogelstein, B. June 1990. A genetic model for colorectal tumorigenesis. Cell 61 (5): $759-67$.

[2]. Gerhard Krauss, Wiley, V.C.H. Third Edition 2003 Verlag Gmbh and Co. Weinheim.

[3]. Alberts, Bray, Lewis, Raff, Roberts, Watson, J.D. 1983. Molecular Biology of the cell. Garland, New York.

[4]. Norbury, C., Nurse, P. 1992. Animal cell cycles and control. Annu Rev. Biochem. 61:441.

[5]. Kleinsmith, Lewis, J. 2006. Principles of cancer biology. San Francisco: Pearson Benjamin Cummings. ISBN 978-0-8053-4003-7.

[6]. Zetterberg, A., Larsson, O., Wiman, K.G. 1995. What is the restriction point? Curr Opin Cell Biol. $7: 835-42$.

[7]. Sarasin, A.2003. An overview of the mechanisms of mutagenesis and carcinogenesis. Mutat Res 544 (2-3): 99-106.

[8]. Schottenfeld ,D., Beebe-Dimmer, J.L.2005. Advances in cancer epidemiology: understanding causal mechanisms and the evidence for implementing interventions. Annu Rev Public Health 26: 37-60.

[9]. Renan, M.J. 1993.How many mutations are required for tumerogenesis? Indications from human cancer data. Mol Carcinog.7:139.

[10]. 10.Pawson, T., Warner, N. 2007. Oncogenic re-wiring of cellular signaling pathways. Oncogene 26:1268-1275.

[11]. Weinberg RA. Oncogenes and multistep carcinogenesis. In: Weinberg RA, editor. Oncogenes and the molecular origins of cancer. New York: Cold Spring Harbor; 1989. p. 307-26.

[12]. DeVita VT, Hellman S, Rosenberg SA. Cancer: Principles and Practice of Oncology. 6th ed. 2001; 207-215.

[13]. Ringer DP, Schniper LE. Principles of Cancer Biology. In: Lenhard RE, Osteen RT, Gansler T, eds. Clinical Oncology. Atlanta, GA: American Cancer Society; 2001: 25-30.

[14]. Kopras, E.2004. Genetic alterations and DNA repair in human carcinogenesis. Semin Cancer Biol 14 (6): 441-8.

[15]. Croce, C.M., Shander, M., Martinis, J. 1979. Chromosomal location of the genes for human immunoglobulin heavy chain. Proc Nat1 Acad Sci U S A 76:3416-3419.

[16]. Croce, C. 2008. Oncogenes and Cancer. The New England Journal of Medicine 358 : 502-11.

[17]. Press, M.F., Bernstein, L., Thomas, P.A. 1997. HER-2/neu gene amplification characterized by fluorescence in situ hybridization: poor prognosis in node-negative breast carcinomas. J Clin Oncol 15:2894-2904.

[18]. Pierotti MA, Schichman SA, Sozzi G, Croce CM. Oncogenes. In: Bast RC, Kufe DW, Pollock RE, Weischselbaum RR, Holland JF, Frei E, eds. Cancer Medicine. Hamilton, Ontario: BC Decker Inc; 2000: 56-66.

[19]. Nobel Prize in Physiology or Medicine for 1989 jointly to J. Michael Bishop and Harold E. Varmus for their discovery of "the cellular origin of retroviral oncogenes". Press Release

[20]. Erikson, J., Martinis, J., Croce ,C.M. 1981. Assignment of the genes for human lambda immunoglobulin chains to chromosome 22. Nature 294:173-175.

[21]. Erikson, J., Nishikura, K., ar-Rushdi, A. 1983. Translocation of an immunoglobulin kappa locus to a region 3 ' of an unrearranged cmyc oncogene enhances c-myc transcription. Proc Natl Acad Sci U S A 80:7581-7585.

[22]. Capon, D.J., Chen, E.Y., Levinson, A.D., Seeburg, P.H., Goeddel, D.V. 1983. Complete nucleotide sequences of the T24 human bladder carcinoma oncogene and its normal homologue. Nature 302:33-37.

[23]. McCoy, M.S., Toole, J.J., Cunningham, J.M., Chang, E.H., Lowy, D.R., Weinberg, R.A. 1983. Characterization of a human colon/lung carcinoma oncogene. Nature 302:79-81.

[24]. Tsujimoto, Y., Yunis, J., Onorato-Showe, L., Nowell, P.C., Croce, C.M. 1984. Molecular cloning of the chromosomal breakpoint of B cell lymphomas and leukemias with the $\mathrm{t}(11 ; 14)$ chromosome translocation. Science 224:1403-1406.

[25]. Tsujimoto, Y., Cossman, J., Jaffe, E., Croce, C.M. 1985. Involvement of the bcl-2 gene in human follicular lymphoma. Science 228:1440-1443.

[26]. Tsujimoto, Y., Gorham, J., Cossman, J., Jaffe, E., Croce, C.M. 1985. The t(14;18) chromosome translocations involved in B-cell neoplasms result from mistakes in VDJ joining. Science 229:1390-1393.

[27]. Adams, J.M., Cory, S. 2007. The Bcl-2 apoptotic switch in cancer development and therapy. Oncogene. 26:1324-1337.

[28]. Adams, J.M., Harris, A.W., Pinkert, C.A. 1985. The c-myc oncogene driven by immunoglobulin enhancers induces lymphoid malignancy in transgenic mice. Nature 318:533-538.

[29]. Leder, A., Pattengale, P.K., Kuo, A., Stewart, T.A., Leder, P. 1986. Consequences of widespread deregulation of the c-myc gene in transgenic mice: multiple neoplasms and normal development. Cell 45:485-495.

[30]. Bishop, J.M. 1991. Molecular themes in oncogenesis. Cell 44:235-248.

[31]. Tomlins, S.A., Rhodes, D.R., Perner, S. 2005. Recurrent fusion of TMPRSS2 and ETS transcription factor genes in prostate cancer. Science 310:644-648.

[32]. Rodenhuis, S. 1992. Ras And human tumors. Semin Cancer Biol 3:241-247.

[33]. Beaupre ,D.M., Kurzrock, R. 1999. RAS and leukemia: from basic mechanisms to gene-directed therapy. J Clin Oncol 17:10711079.

[34]. Davies, H., Bignell, G.R., Cox, C. 2002. Mutations of the BRAF gene in human cancer. Nature 417:949-954.

[35]. Frattini, M., Ferrario, C., Bressan, P. 2004. Alternative mutations of BRAF, RET and NTRK1 are associated with similar but distinct gene expression patterns in papillary thyroid cancer. Oncogene 23:7436-7440.

[36]. Alt, F.W., Kellems, R.E., Bertino, J.R., Schimke, R.T. 1978. Selective multiplication of dihydrofolate reductase genes in methotrexate-resistant variants of cultured murine cells. J Biol Chem 253:1357-1370.

[37]. Cowell, J.K. 1982. Double minutes and homogeneously staining regions:gene amplification in mammalian cells. Annu Rev Genet 16:21-59. 
[38]. King, C.R., Kraus, M.H., Aaronson, S.A. 1985. Amplification of a novel v-erbB-related gene in a human mammary carcinoma. Science 229:974-976.

[39]. Schwab, M., Alitalo, K., Klempnauer, K.H. 1983. Amplified DNA with limited homology to myc cellular oncogene is shared by human neuroblastoma cell lines and a neuroblastoma tumour. Nature 305:245-248.

[40]. Press, M.F., Bernstein, L., Thomas, P.A. 1997. HER-2/neu gene amplification characterized by fluorescence in situ hybridization: poor prognosis in node-negative breast carcinomas. J Clin Oncol 15:2894-2904

[41]. Joensuu, H., Dimitrijevic, S. 2001.Tyrosine kinase inhibitor imatinib (STI571) as an anticancer agent for solid tumours. Ann Med 33:451-455. 42. Finger, L.R., Harvey, R.C., Moore, R.C.A., Showe, L.C., Croce, C.M. 1986. A common mechanism of chromosomal translocation in T- and B-cell neoplasia. Science 234:982-985.

[42]. Betsholtz C, Karlsson L, Lindahl P. Developmental roles of platelet-derived growth factors. Bioessays 2001;23: 494-507.

[43]. Liu J, Xu R, Jin Y, Wang D. Triplex targeting of human PDGF-B (c-sis, proto-oncogene) promoter specifically inhibits factors binding and PDGF-B transcription. Nucleic Acids Res 2001;29:783-91.

[44]. Heldin CH, Westermark B. Mechanism of action and in vivo role of platelet-derived growth factor. Physiol Rev 1999;79:1283-316.

[45]. Sporn MB, Roberts AB. Autocrine growth factors and cancer. Nature 1985;313:745-7.

[46]. Minoletti F, Miozzo M, Pedeutour F, et al. Involvement of chromosomes 17 and 22 in dermatofibrosarcoma protuberans. Genes Chromosomes Cancer 1995;13:62-5.

[47]. Grimm SL, Nordeen SK. Mouse mammary tumor virus sequences responsible for activating cellular oncogenes. J Virol 1998;72:9428-35.

[48]. Zwick E, Bange J, Ullrich A. Receptor tyrosine kinase signalling as a target for cancer intervention strategies. Endocr Relat Cancer 2001;8:161-73.

[49]. Arteaga CL. Epidermal growth factor receptor dependence in human tumors: more than just expression? Oncologist 2002;7Suppl 4:31-9.

[50]. Pollock PM, Meltzer PS. Lucky draw in the gene raffle. Nature 2002;417(6892):906-7.

[51]. Vallar L. Oncogenic role of heterotrimeric G proteins. Cancer Surv 1996;27:325-38.

[52]. Cantley LC, Auger KR, Carpenter C, et al. Oncogenes and signal transduction. Cell 1991;64:281-302.

[53]. Bourne HR, De Franco AL. Signal transduction and intracellular messengers. In: Weinberg RA, editor. Oncogenes and the molecular origins of cancer. Cold Spring Harbor, NY: Cold Spring Harbor Laboratory Press; 1989. p. 97-124.

[54]. Kaziro Y, Itoh H, Kozasa T, et al. Structure and function of signal-transducing GTP-binding proteins. Annu Rev Biochem 1991;60:349-400.

[55]. Luo J, SoliminiNL, ElledgeSJ. Principles of Cancer Therapy: Oncogene and Non-oncogene Addiction. Cell $2009 ; 136(5): 823-837$. doi:10.1016/j.cell.2009.02.024.

[56]. Hanahan D, Weinberg RA. The hallmarks of cancer. Cell 2000;100:57, 70. 